\title{
SOCIO-ECONOMIC DEVELOPMENT AND ITS AXIOLOGICAL ASPECTS
}

\author{
ZBYSZKO CHOJNICKI \\ Adam Mickiewicz University, Institute of Socio-Economic Geography and Spatial Management, \\ Poznań, Poland \\ Manuscript received May 15, 2010 \\ Revised version June 5, 2010
}

CHOJNICKI Z., Socio-economic development and its axiological aspects. Quaestiones Geographicae 29(2), Adam Mickiewicz University Press, Poznań 2010, pp. 7-17. ISBN 978-83-232-2168-5. ISSN 0137-477X. DOI 10.2478/ v10117-010-0010-9.

ABSTRACT. The article presents notions and issues concerning socio-economic development in an axiological perspective. Their presentation is limited to those the present author considers valid, and ignores their wider context as expounded in the various theories of socio-economic development.

Underlying the axiological approach to socio-economic development is the opinion that the character of and research on socio-economic development are not neutral axiologically because values are an inherent component of human activity; they stimulate it and give it a direction. The knowledge concerning human activity makes use of evaluative concepts and judgements.

The article discusses: (1) the concept of socio-economic development, (2) basic axiological notions, and (3) axiological problems of socio-economic development.

KEYWORDS: socio-economic development, axiological concepts, needs and values

Zbyszko Chojnicki, Institute of Socio-Economic Geography and Spatial Management, Adam Mickiewicz University, ul. Dziegielowa 27, 61-680 Poznań, Poland

\section{The concept of socio-economic development}

Socio-economic development is a key concept central to any problem of change in the socio-economic sphere. Its significance is aptly expressed by Stemplowski (1987: 5), who states that "the concept of development functions as both, a product of an optimistic vision and an articulation of social interests, and a tool of analysis."

In the research on socio-economic development one can find a variety of conceptions of development. Rather than discussing them, I shall focus on the construction of the concept of socio-economic development based on two issues: (a) the scope of the concept of this type of development and its reference, and (b) the nature of socio-economic development.

\subsection{The scope of the concept of socio-economic development and its reference}

Socio-economic development embraces changes taking place in the social sphere, mostly of an economic nature. Even though economic aspects come to the fore in the research on change in the 
economy (a study of economic phenomena and processes), they cannot be isolated from social aspects. Hence a more apt term for the change and the development is 'change and socio-economic development' combining the two aspects.

It is worth noting that, according to Chołaj (1998: 16), the science of economics distinguishes political economy in the classic sense. "It preserves its functions (...) concerning the economic aspects of a society's life. This domain of economic theory is interested in the types of socio-economic systems, ownership relations, and interests and motivation behind economic activity".

Underlying the research on and substantive interpretation of social reality is a systems approach and a dynamic approach.

The systems approach basically consists in viewing reality in systemic terms. Social reality is then seen as made up of various social systems occurring at a variety of complexity levels, performing different functions, and assuming a diversity of forms. Social systems emerge, change and disappear as a result of operation of a variety of processes, both social (economic, political, cultural) and natural.

A classification of social systems is a highly complex and complicated matter, and I shall not attempt to present any here. However, there is a type of social systems that perform a basic role in shaping the life and activity of territorially delineated social groups. Those are territorial social systems.

Territorial social systems can be defined as social systems in which a human community occupies, develops and controls a specified area on the Earth's surface, i.e. a territory, on a permanent basis (Chojnicki 1988, 1999). What differentiate it from other social systems are: (1) heterogeneity of composition, i.e. the occurrence not only of the human community but also of a material substratum providing a living environment for the people; (2) multi-aspect and global integration, i.e. predominance of internal links over external ones, with the internal links consisting of three main types of relations of a system-forming nature: economic, political and cultural; (3) self-organisation, i.e. self-regulatory and self-control mechanisms keeping the system in operation; and (4) differences in the spatial scale or range (local, regional, national, supra-national, global) with which different functions and degrees of openness are associated.

The dynamic approach should be treated as complementary to the systems one. It is only in combination that those two approaches provide a basis for a holistic treatment of social systems. On the one hand, no system has a static, immutable character, and on the other hand, a systems approach to objects allows a better insight into and representation of the complexity, the various aspects and mutual relations occurring in the course of their change.

Generally, the dynamic approach addresses changes in systems. This does not only concern changes in the global properties, components and structure of the systems, but also in their surroundings and external links.

An insight into changes in social systems, especially territorial social systems, is particularly difficult owing to their huge complexity, internal and external structural entanglement, and an uneven rate of change in their components. There is certainly hardly a person who doubts that social systems do change; the point is, how they do it.

\subsection{The character of socio-economic development}

In principle, the concept of development rests on that of change. Change is a transition from one state of affairs to another. In this approach, development can be defined as a series of changes characterised by such properties as irreversibility, spontaneity, and a monotonic character (Krajewski 1977: 26), a reference to the concept of structure (Zamiara 1977: 50), and directionality (Chojnicki 1989). Without going into the details of those properties, or formulating any basic (ontological) definition of development, I shall pass on to a characterisation of socio-economic development, but still keeping in mind the fundamental sense of development.

The definition of socio-economic development as a series of changes involves stating what characterises those changes and what determines them. In other words, we have to determine what changes count as socio-economic development. To present the specific nature of socio-economic development, we must refer to the character of proc- 
esses and goals of changes making up this type of development. However, since there is much arbitrariness in understanding and using them, I propose the adoption of the following assumptions.

The nature of socio-economic development is determined by development processes and/ or development targets. Generally, those processes are internally ordered sequences of change in states of affairs, or stages in which some states determine other states that follow them. This determination assumes various forms: causal, stochastic, etc.

From an activistic point of view, two basic types or models of process can be distinguished: 1) spontaneous processes, and 2) target-oriented processes.

Spontaneous processes in a socio-economic system are not targeted on any final states as specified development goals resulting from people's intentional and rational activity. They are not intentionally activised and steered by people, being in principle of a self-organising character. Their course and states regarded as final can be anticipated if one learns the mechanisms underlying them. It is said about their final state that 'it has appeared all by itself', or that it has evolved in a historic process.

In turn, target-oriented processes in a socio-economic system are guided by the activity and behaviour of people (steering, control) and designed to achieve certain specified final states that can be goals of this activity. What characterises targetoriented processes, Sztompka (2002: 439) claims, is "first, that no stage of a process is identical with any other stage (hence the process is irreversible), and secondly, that each later stage makes the state of the system closer (more similar) to some distinguished state, whether preferred, wishedfor, or just the opposite, perceived as undesirable (hence to some target, standard: a sought ideal, or on the contrary, an unavoidable fatal end)".

The processes of socio-economic development are its dynamic components designed to achieve its targets. According to Sztompka (2002: 440), development processes "differ from other targetoriented processes by two additional properties: a) the direction of a process is positive, i.e. with time there is an increase in the level of a variable or a set of variables in terms of which we consider the process (e.g. when the population number grows, we speak of demographic development; when there is a rise in the global product of a society, we speak of economic development) (...), and b) a directional sequence of social changes is set in motion, driven by intra-social mechanisms (i.e. immanent, endogenous, or included within the system in question)". It should be added that also exogenous factors are at work here because each system operates in an environment which affects the system through various external factors.

Thus, socio-economic development is made up of processes caused by exo- and endogenous factors which determine the course and direction of the development. It should also be noted that socio-economic processes do not work in isolation from other processes and that usually they are preceded by, or are consequences of, other processes. Factors of socio-economic development themselves cannot be described closer in general terms because they differ depending on the set of conditions produced by a concrete historical and geographical situation in which socio-economic changes take place. The regional development factors of the present-day socioeconomic transformation of Poland include: the institutional sphere, the business environment, innovativeness, social climate, and foreign investment (Chojnicki \& Czyż 2004: 17).

A characterisation of the goals of socio-economic development poses no less difficulties. It is generally assumed that we can talk about them in a situation in which it is possible to influence development processes in a purposeful and rational way, to steer or create them. The goals determine the character of measures taken to implement them. Hence, there arises the question of the relation between goals and values. If we accept the commonly held opinion that values (evaluations, norms) are inseparable from human activity, that they stimulate it and give it a direction, then values set the goals of the activity that can be evaluated and described in normative terms. The same also refers to goals of socio-economic development.

\section{Basic axiological concepts}

The basic axiological concepts in the sense of value theory are the concepts of value, evaluation 
and norm, except that moral norms as duties and rules regulating people's activity are included in ethics.

Value is understood in a variety of ways, as manifested by disputes about its definition (cf. Kloska 1982). I shall restrict myself to a characterisation of only those concepts of value that can be useful in our reflections on socio-economic development.

As the starting point, let us discuss two understandings of value: substantive and attributive. In the substantive approach, value is understood as specific intentional objects, e.g. good or evil; in the attributive approach, as characteristics evaluating objects, events or processes, i.e. as evaluations. It is fairly difficult to determine the character of value and evaluation independently of each other because those concepts are interconnected. Evaluations predicate of objects or their states that they are valuable, or characterise them in terms of certain evaluative standards. They are judgements or statements saying what is good or bad, useful or useless, etc.

Norms, in turn, state what should be, how to behave or act in the given circumstances, what states of affairs should or should not exist. Several kinds of behaviour norms are distinguished. In the context of our reflections, worth noting is the division of norms into legal and moral. According to Ziembiński (1981: 14), "Legal norms are treated as norms with a thetic justification in the form of acts establishing them that are passed by the organs of a state capable of enforcing respect for those norms. (...) Moral norms are primarily norms with an axiological justification relying on special types of evaluation of an entity supposed to obey those norms".

Of special significance with reference to the sphere of people's activity is the differentiation between autotelic and instrumental values. Autotelic values have an absolute character and are autonomous in the sense that they do not depend on their serviceability or usefulness. Instrumental values have a relative character; they are seen as actual or intentional objects useful for someone, or as evaluations of objects (things) that determine their usefulness. According to Znamierowski (1957: 218), values "are instrumental when they are a means to an end, that is, when they have use value". Instrumental values can better be characterised in Bunge's (1996: 220) words, according to whom " $X$ is a value" is short for " $X$ is valuable for someone or something, in some respect and in certain circumstances, and in some end".

From the utilitarian point of view, it is important to distinguish between instrumental evaluations and norms. Instrumental evaluations concern situations in which some states are assessed in terms of their consequences and effects they produce (Nowak 1985: 271). Ziembiński (1981: 12), in turn, differentiates between two kinds of elements in instrumental evaluations: an intellectual element, consisting in the statement that a state of affairs entails another, and an element of evaluation of the effects anticipated.

Instrumental norms describe a way of operation or behaviour effective in achieving certain states of affairs, or rather certain goals. Hence, they have the form: "in order to achieve this and that, one should behave so and so" (Nowak 1985: 272).

Two further issues should also be addressed here. One involves the cognitive status of evaluations and norms in their fundamental rather than utilitarian sense, and especially their adequacy, namely truth and falsehood. Standpoints on this matter are divided. On the one hand, it is claimed that evaluative expressions do not describe reality, hence they cannot be qualified as true or false; thus, a sharp distinction is made between facts and values. On the other hand, they are assigned a logical value. The argumentation for this standpoint is too extensive to quote here. One of the arguments is that with reference to norms there is always a tacit thesis about the possibility of the action or behaviour which the norm concerns and this thesis does have a logical value, i.e. is true or false. The opinion about evaluations and norms having no logical value does not refer to instrumental evaluations and norms, which explicitly presuppose the truth of the thesis about a relationship between modes of operation and the attainability of some states of affairs.

The other question concerns the double content of concepts involving socio-economic reality that contain descriptive and evaluative elements. Such terms as 'capitalism', or 'capitalist economy', or 'social equality' also carry an evaluative load apart from a descriptive content if they are 
not considered neutral by their user, who assigns them a positive or a negative value (Nowak 1985: 138).

The complexity and multi-dimensional character of values, evaluations and norms in people's behaviour and activity is aptly presented by Gaus (1990: 1): "Some things we like, or find interesting, or useful; other things we abhor or find distasteful. We judge some objects and activities to be valuable or disvaluable, and sometimes we work hard to appreciate that which we believe to be of value. We compare the value of a multitude of things, activities and states of affairs, and these comparisons are central to our deliberations about what we should do. We pursue what is of value, avoid or attack what is disvaluable; we plan our lives around our most cherished values. And we constantly argue with each other about what really is and is not valuable, yet nothing surprises us less than others valuing that in which we can find little or no value".

\section{Axiological problems of socio-economic development}

The following issues will be addressed now: (a) kinds of value in socio-economic development, (b) relations between needs and values, (c) the role of value in the structure of socio-economic development, and (d) the axiological nature of socio-economic progress.

\subsection{Kinds of value in socio-economic development}

The basis for determining the axiological character of socio-economic development is a division of values into entity- or activity-oriented.

In the entity-oriented approach, a distinction is made between individual and public values. Individual, or personal, values concern people's situation in life. Some are autotelic in nature; those are values that people appreciate in themselves, e.g. justice (Grzegorczyk 1983: 38). Other are instrumental; they embrace what individuals strive for, what goals they want to achieve, what needs to satisfy. Among personal values Bunge (1996: 221) counts biological ones (e.g. health, longev- ity) and psychological ones (e.g. a sense of wellbeing). Public values refer to activity in the public sphere, especially to goals set in socio-economic policy. They express what human communities and social groups seek, as well as their collective needs. In the activity-oriented approach, which refers to kinds of activity pursued, values are divided into economic, social, political, cultural and ecological (cf. Hillier 1999).

In the field of socio-economic development, economic value comes to the fore. The concept is highly complex and features in several economic theories; it is also a matter of dispute among various orientations or schools of economic thought in history (cf. Dyke 1981; Blaug 1992). Economic value is instrumental in nature. According to Dyke (1981: 22), of fundamental importance is a distinction drawn by Adam Smith between use value and exchange value. "This concept of use value ("usefulness", "utility") reflects some of our commonsense understanding of value. (...) The concept relates the objects that are manufactured, bought, sold and traded to the lives in which they are used. Usually we don't try to get something that's going to be useless to us. (...) The concept of exchange value captures another part of our commonsense understanding of value. Many times when we ask about the value of something we want to know what it costs. That means we want to know how much money we'd have to exchange for it."

In this approach, exchange value occurring in a market economy is of a quantitative and pecuniary nature, and is a basic, inalienable, expression of economic value. It is a rudimentary information and regulatory instrument in economic activity. In principle, use value also has an economic character, but it contains aspects other than economic, e.g. aesthetic, cultural, etc.

When discussing the character and role of economic values in economic development, money value is thought to concern primarily economic growth and only partly socio-economic development.

There have been hot disputes about economic values as goals of socio-economic development. They are mostly connected with the criticism of the capitalist economy on the part of proponents of so-called radical political economy (see Sayer 1995). According to Sayer (1995: 178), there 
are serious conflicts between use value and exchange value in defining the goals and operation of economic systems. As he claims, "Under all of market systems, the goal of production becomes expressed in exchange-value terms in the form of profit, with use value becoming a means to the end. What might otherwise be substantive goals for providing certain use values become subordinated to the need to minimize costs or maximize revenue. (...) Yet the dominance of exchange value as a regulator of economic activity also leads to deeply irrational behaviour as in crises of overproduction".

Social values concern the existence and condition of a community of people (e.g. justice, quality of life) and those potential and actual objects that satisfy people's collective needs (e.g. prosperity, safety, healthy living conditions). They are difficult to define because the concept of 'social' has a very wide scope and there are no clear-cut criteria of its distinction. This especially refers to how social values relate to economic value. Social values are treated as superior to the economy ('supra-economic') or on a par with it ('extraeconomic'). Prosperity is a supra-economic value since it embraces not only economic components, but also such elements as the satisfaction of specified needs. Social values occurring at the level of economic values, e.g. a population's standard of living, may compete with economic values, e.g. full employment. Associated with economic and social values are political, cultural and ecological ones.

Political values concern various aspects of political life, and especially the character and role of the state and authority. Roughly two kinds of those values can be distinguished. One involves the character and role of state power in the relations among states or within an organisation of states (e.g. the European Union). One of such values is sovereignty. The other kind embraces values concerning the character of a state system, e.g. a democratic system and political stability, and values reflecting the authority-citizen relationship, e.g. civil liberties, political participation, etc.

Cultural values concern the inventive and educational spheres and the satisfaction of people's needs in this field. They refer to both, human behaviour (learning) as well as symbolic (scien- tific knowledge) and material products (a work of art). Examples of such values are the effectiveness of learning, universality of education, or scientific advances.

Ecological values concern the attitude towards the state of nature that has formed, and keeps forming, as a result of the impact of society on it and its feedback. Nature itself is increasingly understood in social terms as man's natural environment to which social practices can be applied, e.g. in the form of management. This social reification of nature places it conceptually among issues of socio-economic development. In this situation studying the state of and changes in nature in axiological terms leads to the identification of values that are taken into account when determining goals of socio-economic development. Among the basic values of the ecological type are the cleanliness of nature, ecological equilibrium, and ecological order.

When determining goals of socio-economic development, it is crucial to draw up a list of values and order them into a hierarchical system. However, this requires clear-cut criteria of the identification of values and their comparability (subordination or superiority). The basis of such a system is a choice of the top-ranking values. In the face of the variety of values, there arises the problem of which kind is to be taken into consideration, the more so as they can be contradictory. The justification of the choice is mostly of a doctrinal nature, being prompted by various theories of socio-economic development. This issue is hard to objectivise, so it often reflects the ideological preferences of development theoreticians.

\subsection{Needs and values}

The concept of a need is ambiguous. I follow Kocowski (1982: 69) in stating that "a need is simply a condition of a person's goal. A concrete condition can be described in detail by the matter of a need. In describing or analysing needs, we usually speak of 'objects of need'. Hence the term 'need' can be regarded as equivalent to the term 'an object of need'."

The categorisation and listing of human needs is highly controversial. Kocowski, who presents such a list, distinguishes five main categories 
of human needs: existential needs, procreation and development needs, functional needs, social needs, and psychic needs.

As to the relationship between values and needs, Misztal (1980) believes there to be two standpoints: one, that they are disconnected, the other, that they are mutually dependent. In the latter, one can speak of values affecting needs and the other way round. With reference to needs determined mostly biologically and socially, Misztal (1980: 127) presents the relations holding between values and needs as follows: "Values understood as objects are means of satisfying needs, both biological and social. Values understood as beliefs that are elements of culture can be seen as determinants of social needs or as a specific justification of biological needs. Values that are elements of the awareness of individuals can be a source of their needs or appear in response to their pre-formed needs".

Goals and values cannot be considered in abstraction from the character of needs, and vice versa, because each group affects the other. The appearance and formation of new needs largely depend on the possibility of their satisfaction and change with socio-economic growth.

\subsection{Axiological aspects of the structure of socio-economic development}

Both goals and processes of socio-economic development have a marked axiological character. I shall focus on two out of the many issues involved in this problem: A. the axiological character of development goals, and B. the axiological aspect as an evaluative coefficient in development processes.

A. Underlying the axiological character of development goals is the question of whether development goals are always axiologically coloured, or whether they can be axiologically neutral. In principle, development goals are assumed to have an axiological character. To simplify the matter, I shall reduce it to the thesis: 'goals are values'.

First of all, one should not interpret this thesis as claiming a conceptual identity of goals and values in the sense of ontological categories, although such a formulation often appears verbally. We say, e.g., that safety is a value, and that safety is a goal of development. Hence the relations between goals and values can be seen in two ways: a) goals implement values; and b) goals undergo evaluation.

The first approach emphasises that, while separate, goals and values are interrelated. This is reflected in judgements concerning values and goals. When e.g. 'people's safety' is considered a value, the goal implementing it can be formulated as 'ensuring safety to people'.

The other approach - goals undergo evaluation - refers to a substantive understanding of goals as distinct final states of development. Depending on the criteria adopted, they can be qualified as good or bad, positive or negative, useful or useless for someone or something.

In rejecting their conceptual identity, both approaches define their significance through relations holding between them.

B. The axiological aspect of the processes of socio-economic development designed to achieve some goals can be defined as an evaluative coefficient referring primarily to the course and operation of those processes and factors that condition or determine them. Those processes can be regulated and controlled depending on the extent to which they can be steered. Both the course and operation of those processes, the effect of factors on them, and their regulation (regulatory measures) can be assessed in terms of their effectiveness and success in achieving the target states set as development goals.

In an activistic approach, regulatory measures are means to an end; together with some specified goals they form a goals-means system, also called a purposeful (target-oriented) action. It should be noted that the action may not lead to the desired end (a target state), and that the measures themselves may have unplanned side effects, both positive and negative. Target-oriented actions are assessed as effective if their result is close to the goal set. The effectiveness is usually gradable.

Target-oriented actions are an indispensable component of socio-economic development. However, not all processes are controllable through them. This refers especially to changes in socio-economic systems displaying a high complexity of internal and external interactions. It is 
a major problem of socio-economic development policy, both at the national as well as regional and local scales.

The chief instrument regulating target-oriented actions is social rules. The concept of social rules itself is understood in a variety of ways depending on their cultural context (cf. Sztompka 2002: 259). With reference to socio-economic activity and development, social rules are thought to be instrumental norms concerning the behaviour and activity of people and social groups, usually target-oriented. They specify modes of operation or behaviour seeking to achieve certain states. They are thus 'recipes' for obtaining something. If they are to be effective, they have to be at least compatible with social and natural regularities. An example can be the ineffectiveness of measures that do not follow the lex persimoniae (Chojnicki 1992, 1999: 386). The steering of the goal-oriented type of development processes must be consistent with the rules underlying development processes.

\subsection{Axiological aspects of socio-economic development}

When addressing this matter, I shall concentrate on two issues: (A) socio-economic progress, and (B) socio-economic development as an object of evaluation.

(A) The concept of progress is contained in that of development. It can be treated as a version of the evaluative type of development concept (Chojnicki 1989). According to Krajewski (1977: 33), "progress is taken to mean development from (...) lower to higher levels. Thus, the definition of progress rests on the definition of 'being higher'." Hence, the terms 'higher' /'lower' are thought to be evaluative.

In this approach, socio-economic progress is the kind of development in which the direction of change is evaluated positively. The positive character of the direction of change defines a transition from states appreciated lower to those appreciated higher as development stages. This implies a hierarchy of values characterising those states.

The opposite of progress is regression, which occurs when development backslides to states that took place earlier and were appreciated lower, or to states evaluated lower than the state already attained.

Progress (and regression) can be defined in absolute or relative terms. However, the definition of absolute progress poses fundamental difficulties connected with establishing objective criteria of progress. With reference to socioeconomic development, they could be taken to include enhancing the diversity and integration found in socio-economic systems (cf. Krajewski 1977: 36; Chojnicki 1989).

The difficulties connected with establishing objective (absolute) criteria of progress with reference to changes in the socio-economic sphere justify the belief that they should be considered in a relative-evaluative approach. As Zamiara (1977: 51) claims, the concept of progress "reflects (...) a human evaluation scale rather than the objective features of the world, the fact that we generally tend to evaluate the processes of upward development positively and those of downward development negatively".

A relative approach to progress in the socioeconomic sphere (in society) can be characterised as follows. According to Sztompka (2002: 442$-443)$, "There is no change that is progress (or regression) in itself; it can be qualified as progress when it has become an object of a positive evaluation popular in some community and formed on the basis of some axiological criteria. (...) Hence, progressiveness (regressiveness) is always relativised. First, to a community that formulates such evaluations. What one group, class, or nation considers progressive need not be viewed as such by another community." For example, an agricultural reform. "Secondly, progressiveness is relativised historically: what is perceived as progress today need not have been treated as progressive yesterday, and could have even been considered regressive". For example, new inventions, loose morals. "Thirdly, progressiveness (...) is relativised to the adopted criteria of progress (recognised values); what is progressive by one criterion need not be progressive by a rival criterion, and even be considered regression. Thus, industrialisation is progress when the criterion is production growth, but it is not progress when the criterion is the survival of the natural environment".

In characterising progress, of fundamental significance are values adopted to define its crite- 
ria. A big role in this respect is played by ideological doctrines, which themselves rely on explicit or tacit evaluative assumptions.

(B) Socio-economic development as an object of evaluation mostly involves an assessment of its role as an instrument used to work changes in socio-economic reality, and in socio-economic systems in particular. There are several issues to be addressed in this field, of which I shall discuss the following, mostly of an economic nature: (a) development as growth, (b) modernity as the current development stage, (c) the role of development in the transformation of societies and economies, and (d) the ethical aspect of development.

(a) The concept of growth implies a quantitative approach to socio-economic development. It mostly refers to quantitative changes designed to attain goals and economic values that consist in an expansion of the production of goods and services as measured by various indicators of global production, national income, etc. When considering socio-economic development in terms of economic growth, there is talk of high, medium, low, or even zero growth (cf. Chojnicki 1989). Identifying socio-economic development with economic growth is assessed negatively. It is pointed out that economic growth, even considered in terms of achieving economic values, does not always lead to an increase in wealth, full satisfaction of needs, and a better distribution of goods. Hence in the contemporary theories of socio-economic development a primary role of the dynamics of economic growth targeted on purely economic values is being questioned.

(b) The concept of stages in economic development makes it possible to distinguish momentous changes occurring in socio-economic systems. The stages of momentous changes are described in evolutionary-historical or analyticclassificatory terms. An evolutionary-historical approach concerns the history of societies in which successive stages are distinguished that various countries can be assigned to (cf. Chołaj 1998: 57). In an analytical approach, those stages are not identified in the sense of evolutionary-historical stages that each community goes through, but in the form of models (types) of development stages.

Within the theory of development, analytical models of stages of socio-economic development are distinguished. It is a fairly widespread opinion that the present-day stage of development is termed modernity. It is supposed to mark a transition from traditional to modern society. The conception of modernity itself as a model or type of development is equivocal. Sztompka (2002: 508) defines modernisation as "a society advancing in an intentional, premeditated, planned way towards a recognised model of modernity, usually to the standard of an existing society regarded as modern". According to Chołaj (1998: 50), "one cannot put the equality sign between modernisation and modernity. (...) Modernity is an effect of modernisation. In comparison with the traditional one, a modernised society displays fundamentally different parameters. (...) The concept of modernisation refers to a combination of processes that accumulate and interact, viz. generation of capital and mobilisation of resources, development of the productive forces and growth in labour efficiency, urbanisation, popularisation of schooling, secularisation of ethical values and norms, etc. (...) Those phenomena are mutually conditioned since as a rule they occur jointly, or at most some of them are temporarily delayed."

Out of the wealth of problems associated with modernity, one should note the following issues: 1) a division of modernity considered in economic terms into the stages of industrialisation and post-industrialisation; each of them sets different criteria for modernisation processes and gives them a different character; 2) a wider connection of modernity with the European civilisation, hence problems with making it universal enough to cover countries with different cultures; and 3) the formation of a new stage of socio-economic development through the emergence of new economic, social, political and cultural forms and structures termed postmodernity. The conception of postmodernity is an object of debate and has not won full recognition (Harvey 1992; Chojnicki 1993).

(c) Socio-economic development considered as an instrument of transformation of the society and economy of the world is an object of criticism springing from various theories of development, especially their radical versions (cf. Booth 1994; Escobar 1995). The criticism refers to the concept of social development, the development situation of the world, and the nature of goals and values. 
In the first place, it is claimed that the conception of socio-economic development underlying development policy tends to be restricted to issues of economic growth and modernisation activity, which makes it impossible to grasp all the complexity of various development situations in a substantive, a temporal (historical) and a geographical approach (cf. Domański 2004). Therefore, increasingly more attention is paid to the role of ecological and civilisational aspects. This especially concerns the conception of ecodevelopment, environmental protection, and the exploitation of natural resources.

The chief object of criticism is the development situation of the world. There are wide differences in the level of its socio-economic development, both in a geographical approach (backward and underdeveloped countries, the Third World, polarisation, peripherality) and in terms of people's conditions of living and existence. This gives rise to social and political conflicts and tension, both within the community of a country and between states. Those are issues addressed by the research on regional and local development (cf. e.g. Parysek 1996, 1997; Chojnicki \& Czyż 2004; Churski 2008).

The criticism of the development situation of the world refers mostly to the character of the capitalist economy with its various underlying ideological and pragmatic considerations. It is believed that the conception of economic growth and modernisation is determined by the character of the capitalist economy; its mechanisms, operation and values govern socio-economic development.

The matter of the axiological character of socio-economic development is also gaining in importance. First of all, attention is drawn to the predominance of economic values as a basis of evaluation of development and its goals. Disputes about the character of socio-economic development are increasingly axiological disputes. An overall evaluation of development concerns primarily the nature of its chief values. While development is assessed on the basis of evaluation criteria in the instrumental sense, its prime values are regarded as autotelic and defined in an ethical-moral perspective.

(d) What is considered the prime value of development in reflections on the ethical aspects of development is social justice. According to Harcourt (1997: 9), "development has always been about the politics of achieving social justice." It should be added that justice is regarded as a basic ethical and moral category (Ziembiński 1981: 29). When making a survey of views on the character of social justice, Grimes (1999: 66) quotes Friedmann's opinion that "the basis for seeking a greater degree of social justice through development must include human rights, citizen rights, and human flourishing". In this he relies on the encyclical Sollicitudo rei socialis (30 Dec. 1987), in which John Paul II expressed his belief about the moral nature of development. "The central argument of this document is that the essential nature of development is moral and that necessary political decisions for overcoming the obstacles to development are moral decisions" (Grimes 1999: 67).

The problem of the moral-ethical character of development has greatly expanded the set of axiological issues in socio-economic development. This is emphasised by Smith (2000: 157), who claims that "the promotion of development is thus a deeply normative project connected with conceptions of human good." An ethical perspective on socio-economic development opens a new avenue of research in this field and provides a fresh insight into our understanding of the nature of development.

\section{References}

Blaug M., 1992. The methodology of economics or how economists explain. Press Sindicate of the University of Cambridge.

Воотн D., (ed.) 1994. Rethinking social development. Methuen, London.

Bunge M., 1996. Finding philosophy in social science. Yale University Press, New Haven. London

CHojnicki Z., 1988. Koncepcja terytorialnego systemu społecznego. Przeglad Geograficzny, 60, 4: 491-510.

CHOJNICKi Z., 1989. Podstawowe aspekty rozwoju społecznogospodarczego. Samorzad Terytorialny, 18: 107-121.

CHOJNICKI Z., 1992. Współczesne problemy gospodarki przestrzennej. In: Z. Chojnicki, T. Czyż (eds.), Wspótczesne problemy geografii społeczno-ekonomicznej Polski. Wydawnictwo Naukowe UAM, Poznań: 9-19.

CHOJNICKi Z., 1993. Postmodernistyczne zmiany globalnego porządku społeczno-gospodarczego. Studia Regionalne i Lokalne, 12, 45: 166-204.

Chojnicki Z., 1999. Podstawy metodologiczne i teoretyczne geografii. Bogucki Wydawnictwo Naukowe: Poznań. 
CHOJNICKI Z., CzYŻ T., 2004. Główne aspekty regionalnego rozwoju społeczno-gospodarczego. In: J.J. Parysek (ed.), Rozwój regionalny i lokalny w Polsce w latach 1989-2002. Bogucki Wydawnictwo Naukowe, Poznań: 13-24.

ChoŁaj H., 1998. Transformacja systemowa w Polsce. Szkice teoretyczne. Wydawnictwo Uniwersytetu M. CurieSkłodowskiej, Lublin.

Churski P., 2008. Czynniki rozwoju regionalnego i polityka regionalna w Polsce w okresie integracji z Unia Europejską. Wydawnictwo Naukowe UAM, Poznań.

DOMAŃSKI B., 2004. Zróżnicowanie i warunki gospodarki regionów. Suplement do dyskusji na temat teorii Alfreda Löscha. Przegląd Geograficzny, 74 (2): 157-178.

DYKe C., 1981. Philosophy of ecomomics. Prentice Hall, Englewood Cliffs.

Escobar A., 1995. Encountering development. Princeton University Press, Princeton.

Friedmann J., 1992. Empowerment: The politics of alternative development. Blackwell, Oxford.

Gaus G., 1990. Value and justification. Cambridge University Press, Cambridge.

GRIMES S., 1999. Exploring the ethics of development. In: J.D. Proctor, D.M. Smith, (eds.), Geography and ethics. Journeys in moral terrain. Routledge, London: 59-71.

GrZegorczyK A., 1983. Próba treściowego opisu świata wartości i jej etyczne konsekwencje. Ossolineum, Wrocław.

Harcourt W., 1997. The search for social justice. Development, 40: 5-11.

Harvey D., 1992. The condition of postmodernity. Blackwell, CAMBRIDGE, OXFORD.

Hillier J., 1999. What values? Whose values? Ethics. Place and Environment, 2 (2): 179-199.
KLOSKA G., 1982. Pojęcia, teorie i badania wartości w naukach społecznych. PWN, Warszawa.

Kocowski T., 1982. Potrzeby człowieka. Koncepcja systemowa. Ossolineum, Wrocław.

KRajeWSKI W., 1977. Pojęcia rozwoju i postępu. In: J. Kmita (ed.), Założenia teoretyczne badań nad rozwojem historycznym. PWN, Warszawa: 21-45.

Misztal M., 1980. Problematyka wartości w socjologii. PWN, Warszawa.

NoWAK S., 1985. Metodologia badań społecznych. PWN, Warszawa.

PAryseKJ.,(ed.) 1996. Rozwój lokalny i lokalna gospodarka przestrzenna. Bogucki Wydawnictwo Naukowe, Poznań.

PARYSEK J., 1997. Podstawy gospodarki lokalnej. Wydawnictwo Naukowe UAM, Poznań.

SAYER A., 1995. Radical political economy. Blackwell, Cambridge, Oxford.

SMith D., M., 2000. Moral geographies. Ethics in a world of difference. University Press, Edinburgh.

StemplowsKi R., 1987. Rozwój jako przedmiot dyskusji. In: Ameryka Łacińska. Dyskusja o rozwoju. Warszawa.

SzTompKA P., 2002. Socjologia. Analiza społeczeństwa. Znak, Kraków.

ZAMIARA K., 1977. W sprawie statusu pojęć ontologicznych rozwoju i postępu. In: J. Kmita J. (ed.), Założenia teoretyczne badań nad rozwojem historycznym. PWN, Warszawa: 46-52.

ZiEMBińSKI Z., 1981. Podstawy nauki o moralności. UAM, Poznań.

ZnAMIEROWSKI C., 1957. Oceny i normy. PWN, Poznań. 